\title{
ENTREVISTA COM: ELIO SOMASCHINI - VELEJADOR TRAVESSIA DO ATLÂNTICO NORTE SOLITÁRIO, VOLTA AO MUNDO SOLITÁRIO SKIPER http://www.skipperelio.com
}

ALMEIDA, Marco Antonio Bettine de, Universidade de São Paulo - USP, São Paulo - Brasil

Mesmo longe dos holofotes nacionais nossos atletas da vela são considerados exímios velejadores. Para termos uma idéia da quantidade de conquistas, o Brasil possui 16 medalhas em Jogos Olímpicos, 62 Medalhas em Jogos Pan-Americanos e 67 vezes o título mundial.

Pensando apenas em velejadores contemporâneos, podemos citar Torbel Grael e Robert Scheid. O primeiro foi Campeão da Louis Vuitton Cup 2000, a segunda maior regata do mundo, e Campeão da Volvo Ocean Race 2008/2009, além de medalhas olímpicas e Panamericanas. O segundo foi considerado o melhor velejador do Mundo - ISAF 2001 e 2004, possuindo 145 títulos internacionais. O ano passado Torben Grael recebeu o premio do melhor do mundo e o Scheidt é Heptacampeão mundial da classe laser e creio que já tenha ganho um mundial na Star.

Mas o Brasil possui também excelentes velejadores que estão longe dos holofotes da mídia, mas que tem na modalidade uma forma de vida, seja disputando regatas, passeando na costa brasileira ou, os mais audaciosos, velejando costa a fora. Foi exatamente este modo de vida que despertou o interesse de trazer para este número da Revista Conexões um pouco do mundo da vela, tendo como representante Elio Somaschini, um velejador experiente que deixou sua vida de trabalho em Bragança Paulista (SP) para se dedicar ao 
Barco. A entrevista pretende mostrar olhares sobre a vela, pensá-la como modalidade esportiva de alto-rendimento, como lazer e prazer, e a vela como modo de status.

Elio Somaschini ganhou notoriedade no mundo da vela, inclusive com uma longa entrevista na Revista Náutica publicada em 2011, por fazer em 2010 a travessia do Atlântico Norte em Solitário, a bordo do CRAPUN, cruising/racer Beneteau First 40.7, partindo de Palm Beach (EUA) e chegando em Sagres (Portugal). Atravessar o Atlântico sozinho nos faz lembrar de Julio Verne ou a aventura do grande velejador inglês Shackelton.

O escritor Herman Meville, no livro Moby Dick, descreve com maestria o fascínio do homem pela água. "Porque quase todo o rapaz robusto e sadio de alma fica louco pra ir ao mar? Por que, em vossa primeira viagem como passageiro, vós mesmo sentistes uma vibração tão misteriosa, quando vos disseram pela primeira vez que vós e o navio já não podíeis divisar terra? Por que os persas consideravam sagrado o mar? Por que lhe atribuíram os gregos um deus especial, o próprio irmão de Jove? Por certo tudo isso não deixa de ter sentido. E ainda é mais profundo o sentido daquela história de Narciso, que, por não pegar a imagem, atormentadora e suave, que ele via na fonte, mergulhou nela e afogou-se. Mas essa imagem, nós mesmos a vemos em todos os rios e oceanos. É a imagem do inagarrável fantasma da vida; e esta é a chave de tudo." Talvez seja este o tom da entrevista, este olhar para o desconhecido. 


\section{Elio Somaschini acredito que a pergunta mais intrigante seja: atravessar o Atlântico} sozinho, quais foram os maiores desafios nesta jornada?

Quando o cansaço físico se torna grande, o psíquico começa a fraquejar. Exemplo: os quatro dias de mau tempo entre Bermuda e Açores quando tive que subir até o paralelo 50 empurrado pela natureza e eu não estava preparado para aquele frio. Lábios azuis, batendo dentes, sem dormir mais de 24 horas, e por aí vai. Mas depois que passa você se recupera rapidamente e sente uma grande satisfação. A conquista é única. O maior desafio é a incerteza do amanhã. Logicamente a maior aventura.

A vela é bem desenvolvida na América do Norte e Europa Ocidental, com as grandes regatas de volta ao mundo. Para desenvolver os barcos, cada vez mais tecnologia e conhecimento são empregados. Quem pode ser considerado o grande revolucionário da vela como modalidade esportiva?

Isto tem muito de opinião pessoal, mas para mim os dois maiores foram Eric Tabarly e Mau Piailug. O resto é salsicha. Aí você percebe como sou pequeno e quanto tenho que aprender. Se hoje existe o hydroptere ${ }^{1}$ é por que Tabarly lançou a idéia e fez as primeiras experiências. Se hoje as velas são tão aperfeiçoadas, é conseqüência dos passos iniciais dados por Tabarly. Piailung nos ensinou a velejar apenas olhando as estrelas sem instrumentos no oceano pacífico.

O veleiro é pioneiramente um meio de transporte. Posteriormente, com o surgimento do esporte, ele se institucionaliza. Todavia existem disputas que guardam

\footnotetext{
${ }^{1}$ A l’Hydroptere, que já foi motivo de piada algumas vezes, desde que surgiram seus primeiros modelos, nos anos 70, começa a ser levado a sério depois de uma série de recordes. O barco, que levanta os três cascos da água graças a seu sistema de hidrofólios, era muito instável antigamente. Agora, Thebault começa a almejar recordes mais ambiciosos, incluindo o de travessias oceânicas longas e o da singradura em 24 horas.

Conexões: revista da Faculdade de Educação Física da UNICAMP, Campinas, v. 9, n. 1, p. 199-204, jan./abr. 2011. ISBN: 1983-9030
} 
semelhanças com os antigos desafios da navegação. Quais são estas regatas? Porque elas são importantes?

A America's Cup é a competição mais antiga do planeta (pode ser considerada a primeira modalidade esportiva) e está no meio de uma verdadeira revolução de conceitos que está dividindo as opinões do mundo náutico. Antes ela servia de referência para novidades tecnológicas, como a quilha com winglet. O desenvolvimento da vela com a introdução dos multicascos e as técnicas de construção com novos materiais fizeram com que os barcos pudessem velejar 3 ou 4 vezes mais rápido que o vento! E isso não existia antes! Raramente um monocasco andava mais rápido que o vento!

Muitas pessoas não conhecem o mundo da vela. Acredito ser importante perguntar sobre sensações, sentimentos. Para fazermos inclusive analogias com outras formas de lazer. Para você o que significa velejar?

É a mais pura forma de integração com a natureza. Uma verdadeira aula de vida. Afinal, o vento é o mesmo para todos e cada um vai conforme é capaz de abrir suas velas.

Para conhecermos um pouco mais. Na sua experiência você poderia definir algumas categorias de velejadores?

Com a idade (e o bolso) vão mudando os barcos. Quando jovens queremos velocidade pura, e aí Windsurf, Kite, Laser, 49er, K, Tornado, etc. são os preferidos. Depois a gente vai envelhecendo e começa com barcos cabinados, mas velozes, tipo os Cruiser /Racers (40.7, X, Brenta etc.). Muitos não entram nessa e preferem os cruzeiros e aí têm barcos confortáveis, seguros, lentos, e sonham com viagens longas, mas... não conseguem soltar as amarras, mais ou menos como esses que tem Jipes fantásticos mas moram em São Paulo 
e os usam no máximo para descer a serra pela imigrantes... Há os que motoram (possuem barco à vela, mas utilizam o motor o tempo todo sem utilizar a força do vento), mas acham romântico dizer que tem veleiro (ou não tem dinheiro para comprar um barco a motor cabinado...). E finalmente a categoria que eu me incluo, que são os duros, que velejam e remendam as velas, e vão se divertindo por esse mundo afora na maior paz.

\section{Como está organizado a vela no Brasil?}

Existem federações estaduais e a confederação, além da parte do Comitê Olímpico. A prefeitura de São Paulo tinha um clube na beira da Guarapiranga que se chamava clube Municipal e foi onde eu aprendi muito com grandes velejadores e não precisava ter grana para ir lá... Fechou! Triste.

\section{Conte-nos um pouco da relação com outros velejadores e das descobertas de ser um}

\section{homem do mar?}

A escala de valores se altera completamente! A parte de valores econômicos, como medida, desaparece. Em troca, gestos, sorrisos, dicas, ajudas (mesmo uma simples ajuda sobre onde ir comprar gás) tomam uma magnitude considerável. Encontrei culturas completamente diferentes da nossa e algumas inclusive com hábitos até chocantes, mas o melhor de tudo é perceber que cada cultura serve para adaptar o homem àquele entorno, a aquele meio-ambiente. Talvez o mais fantástico seja finalmente descobrir que a absurda maioria das pessoas são seres bons, amáveis que apenas querem da vida paz, e poder dar felicidade aos seus descendentes. Isto impressiona! 


\section{Palavras Finais...}

Quando você está sozinho no oceano após uns dois ou três dias velejando sem ver terra, já fora das previsões de tempo que você tinha ao partir, os teus sentidos se aguçam. Cada barulhinho do barco te diz algo, você ouve vozes! Claro que isso é fruto da tua imaginação como conseqüência de ruídos do vento nos estais, da água no casco do barco etc. Cada momento é de interação completa com a natureza. Maravilhoso! 